\title{
LECTIN STAINING PATTERNS IN HUMAN GASTRIC MUCOSAE WITH AND WITHOUT EXPOSURE TO HELICOBACTER PYLORI
}

\author{
Mario R. Melo-Junior ${ }^{1 *}$; Carmelita L.B. Cavalcanti' ${ }^{1}$; Nicodemos T. Pontes-Filho ${ }^{1,2}$; Luiz B. Carvalho Jr. ${ }^{1,3}$; \\ Eduardo I. C. Beltrão ${ }^{1,3}$
}

${ }^{1}$ Laboratório de Imunopatologia Keizo Asami, Universidade Federal de Pernambuco, Recife, PE, Brasil; ${ }^{2}$ Departamento de Patologia, Universidade Federal de Pernambuco, Recife, PE, Brasil; ${ }^{3}$ Departamento de Bioquímica, Universidade Federal de Pernambuco, Recife, PE, Brasil

Submitted: July 10, 2007; Returned to authors for corrections: /November 30, 2007; Approved: February 18, 2008.

\section{SHORT COMMUNICATION}

\begin{abstract}
The aim of the present study was to evaluate qualitative changes in the glycoconjugate expression in human gastric tissue of positive and negative patients for Helicobacter pylori, through lectins: Wheat Germ Agglutinin (WGA) and Concanavalin A(Con A). The lectins recognized differently the glycoconjugates in the superficial mucous layer at the gastric tissues. The results suggest a significant change in the carbohydrate moieties present on the surface of the gastric cells during infection.
\end{abstract}

Key-words: Lectin, gastric mucosae, Helicobacter pylori

Half of the world population is infected by the bacterium Helicobacter pylori. This bacterium is intimately associated to the active chronic gastritis besides of being a risk factor for the development of gastric adenocarcinoma (6). Although Helicobacter pylori is nowadays accepted as the major aetiological agent in chronic gastritis in man, many of the factors which determine its pathogenicity are unknown. Via the carbohydrate moieties on its surface the bacterium binds to the gastric mucosae and epithelial cells and after attachment harmful toxins and enzymes act leading to cell damage and an immune response ensues $(3,14)$.

Most of the infectious diseases have as the primary event the adhesion of pathogenic organisms to the host tissue. In many cases this adhesion is mediated by lectins present in the surface of the parasite, which recognizes the carbohydrates in the tissue cell membranes (13). Due to their broad recognition properties, lectins, carbohydrate-binding ubiquitous (glyco)proteins, have found numerous applications in biological and medical areas $(7,8)$.

Lectins are reliable tools used as biomarkers for pathobiochemical alterations of the gastric epithelium during
H. pylori infection as well as glycocalix mapping of $H$. pylori during infection stages $(8,10)$. Lectin histochemistry with Peanut agglutinin (PNA) and Ulex europaeus agglutinin (UEAI) evidenced significant differences in cell surface carbohydrates in gastric epithelium of $H$. pylori negative and positive patients $(4,5)$. This study aims to investigate alterations of the gastric tissue in patients infected and noninfected by this bacterium.

Gastric biopsies $(n=43)$ from patients with active chronic gastritis were classified into $H$. pylori positive and negative groups (Table 1). H. pylori infection was identified by microscopic observation of the bacteria in Giemsa-stained gastric biopsy sections. Paraffin sections $(4 \mu \mathrm{m})$ of human gastric tissues were deparaffinized in xylene and hydrated through graded alcohol. Tissue sections were treated with a $0.1 \%(\mathrm{w} / \mathrm{v})$ trypsin solution at $37^{\circ} \mathrm{C}$ for $2 \mathrm{~min}$, followed by $0.3 \%(\mathrm{v} / \mathrm{v})$ methanolic hydrogen peroxide, for $20 \mathrm{~min}$, for peroxidase-conjugated lectins. Incubation with peroxidase (Per) and fluorescein isothiocyanate (FITC) conjugated lectins (ConA-Per and-FITC, $60 \mu \mathrm{g} / \mathrm{mL}$; WGAPer and -FITC, $60 \mu \mathrm{g} / \mathrm{mL}$ ) was developed for $2 \mathrm{~h}$ at $4^{\circ} \mathrm{C}$. Slides

*Corresponding Author. Mailing address: Laboratório de Imunopatologia Keizo Asami, LIKA, Universidade Federal de Pernambuco, UFPE. Av. Morais Rêgo s/n, Campus Universitário, 50670-910, PE, Brazil. Tel/Fax: (081) 3271 8484/3271 8485. E-mail: mariormj@gmail.com 
Table 1. Clinical profile of patients with and without Helicobacter pylori infection.

\begin{tabular}{|c|c|c|c|c|}
\hline Patient & $\mathrm{n}(\phi / ð)$ & Mean age & Clinical diagnosis & Histological diagnosis \\
\hline H. pylori (+) & $10 / 11$ & 38.6 & Active chronic gastritis & $\begin{array}{l}\text { inflammatory infiltrate } \\
\text { (neutrophiles and lymphocytes) }+ \text { fibrosis }\end{array}$ \\
\hline H. pylori (-) & $12 / 10$ & 42.1 & No symptoms and normal mucosa & Normal mucosa \\
\hline
\end{tabular}

were washed ( $5 \mathrm{~min}$ ) with $10 \mathrm{mM}$ phosphate buffer, containing $0.15 \mathrm{M} \mathrm{NaCl}$ (PBS), $\mathrm{pH} 7.2$, after each step. Lectin-Per was treated with $\mathrm{DAB}-\mathrm{H}_{2} \mathrm{O}_{2}$ solution. Binding evaluation was done through conventional optical and fluorescence microscopy for Per- and FITC-conjugated lectins, respectively.

Inhibition assays were performed using the corresponding lectin specific sugar: methyl-a-D-mannoside for Con A, N-acetylglucosamine for WGA at final concentration of $300 \mathrm{mM}$.

Images of slices of the stained cells (magnification 100x) were obtained using a digital video camera (Sony, Japan) connected to a microscope and processed using OPTIMAS ${ }^{\mathrm{TM}}$, version 6.1 (Optimas Corporation, USA). Fields were chosen randomly from various section levels to ensure objectivity of sampling. The files were then opened in Adobe Photoshop (Adobe Inc. Mountain View, CA) and further processed to assess stained cells.

The images were binarized to black and white and a common threshold level was chosen for representing correct stained cells and minimizing background noise levels (Optimas Commander: Adjust Threshold). To investigate changes in lectin binding patterns revealed by the peroxidase and fluorescein isothiocyanate reaction we employed the following method: red channel images were initially blurred with a Gaussian filter (one pixel for all sample images) to reduce electronic and background noise (Optimas Commander: Filter: Blur: Gaussian blur); eight-bit grayscale levels were expanded linearly so that the whitest point fell at a grayscale value of 255 and the blackest point at 0 ; the images were then so that all points above the chosen grayscale value were included for measurement and those below were excluded.

However, a common threshold level was chosen for all analyzed images to prevent intra-assay variations. We then inverted the images, which changed all white pixels to black ones and vice versa (Optimas Commander: Adjust: Invert), and employed the image processing for further analysis.

Staining control (tissues treated with sugar-inhibited lectins and normal gastric samples) was obtained to minimize distortions in values due to the presence of non-marked cells, thus a correction factor (CF) was applied according to the equation $\mathrm{CF}=\mathrm{s} / \mathrm{S}$, in which $\mathrm{s}$ means relative area of the surface and $\mathrm{S}$, the total measured area.

In the cases that presenting total areas of the tissues containing similar and better histomorphologic conditions, the
Table 2. Comparative lectin staining pattern in human gastric mucosae infected by Helicobacter pylori.

\begin{tabular}{ccccc}
\hline \multirow{2}{*}{ Patient } & \multicolumn{4}{c}{ Lectin } \\
\cline { 2 - 5 } & Con & Con & WGA- & WGA- \\
& A-FITC & A-Per & FITC & Per \\
\hline H.pylori (+) & + & - & ++ & ++ \\
H. pylori (-) & $+1+$ & ++ & $+1+$ & ++ \\
\hline
\end{tabular}

Abbreviation: Con A(Concanavalin A); WGA(Wheat germ agglutinin); FITC (Fluorescein isothiocyanate); Per(Peroxidase).

Stain pattern: none $(-)$; weak $(+)$; moderate $(++)$; strong $(+++)$.

summary of lectin-binding cells per area were developed in three random areas of stained tissues (Total area analyzed for each slice $=12.234 \mu \mathrm{m}^{2}$ ).

Lectin-binding cells were used to calculate (\%) the mean area $($ weak stain $=15-20 \%$; moderate stain $=25-55 \%$; strong stain $=60-95 \%$ ). Semi-quantitative optical analysis was carried out taking account the intensity of staining pattern indicated as weak $(+)$, moderate $(++)$ or strong $(+++)$, according to Özer (11).

In this work, Con A-Per and Con A-FITC showed an intense binding pattern to negative $H$. pylori tissues where antral and corpus glands being highly recognized. Positive $H$. pylori tissues were weakly marked by Con A-FITC. Stroma and gastric epithelium were diffusely stained by WGA-Per and WGA-FITC in both negative and positive patients (Table 2). However, previous studies showed that lectin typing of strains did not differ before and after colonisation by $H$. pylori (9). Notwithstanding gastric colonisation is facilitated by cell wall associated lectin/carbohydrate which permits the bacterium to bind to gastric mucus and the gastric epithelial cells $(1,15)$.

Other study with different lectins reported that the glycocalyx on both spiral and coccoid forms of $H$. pylori was similar in its staining. However, the staining patterns of the lectins varied among them $(2,10)$. In the present report, none of the $H$. pylori forms were specifically stained by Con A and WGA, suggesting absence of their specific carbohydrates, mainly glucose-mannose and $\mathrm{N}$-acetyl-glucosamine, on the surface of the bacterium. Con A and WGA recognized differently the glycoconjugates in the superficial mucous layer in gastric 
tissues diagnosed as positive and negative for $H$. pylori infection. Using similar methodology (12) it was found a significant difference in the PNA binding on gastric epithelium between the two groups.

In conclusion, the Lectin-binding patterns are altered as response of changes in glycoproteins expression accompanying cell maturation and/or disease. In our laboratories, recent study evidenced that lectins binding to human colonocytes and gastric cells can predict malignant and premalignant lesions of gastrointestinal tissues and has potential as a non-invasive screening tool for gastro-colorectal diseases (8).

The results reported here suggest a change in the carbohydrate moieties present on the surface of the ecosystem of the gastric tissue revealed by lectin histochemistry and demonstrate that the surface carbohydrates components of the gastric cells might give new insights in the complex interaction between $H$. pylori and its host. Such findings contribute with additional information which can be used to draw new pharmacological treatments.

\section{ACKNOWLEDGMENTS}

We thank Raquel A.L. Coêlho, Ph.D. for scientific assistance. This work was supported by CNPq (CTPETRO n ${ }^{\circ} 463655 / 001$ ).

\section{RESUMO}

\section{Padrões de ligação de lectinas em mucosa gástrica humana com e sem exposição a Helicobacter pylori}

O objetivo do presente estudo foi avaliar as mudanças qualitativas na expressão de glicoconjugados em tecidos gástrico humano de pacientes infectados ou não pelo Helicobacter pylori, através das lectinas: Wheat germ agglutinin (WGA) e Concanavalina A (Con A). As lectinas reconheceram diferentemente os glicoconjugados nas camadas mucosas superficiais do tecido gástrico. Os resultados sugerem mudanças significantes nas porções de carboidratos presentes nas células gástricas durante a infecção.

Palavras-chave: Lectinas, Mucosa gástrica, Helicobacter pylori

\section{REFERENCES}

1. Cabral, M.M.D.A.; Mendes, C.M.C.; Castro, L.P.F.; Cartelle, C.T.; Guerra, J.; Queiroz, D.M.; Nogueira, A.M.F. (2006). Apoptosis in Helicobacter pylori gastritis is related to cagA status. Helicobacter., 11 (5): 469-476.

2. Cesar, A.C.G.; Cury, P.M.; Payao, S.L.M.; Liberatore, P.R.; Silva, A.E. (2005). Comparison of histological and molecular diagnosis of Helicobacter pylori in benign lesions and gastric adenocarcinoma. Braz. J. Microbiol., 36 (1): 12-16.

3. Errico, D.A.; Medeiros, A.; Miguez, M.; Casaravilla, C.; Malgor, R.; Carmona, C.; Nieto, A.; Osinaga, E. (2001). O-glycosylation in Echinococcus granulosus: identification and characterization of the carcinoma-associated Tn antigen. Exp. Parasitol., 98 (2): 100-109.

4. Ge, Z.H.; Blom, J.; Larsson, L.I. (1998). Ulex europaeus agglutininI binds to developing gastrin cells. Histochem. Cell Biol., 109 (3): 183-88.

5. Hynes, S.O.; Hirmo, S.; Wadström, T.; Moran, A.P. (1999). Differentiation of Helicobacter pylori isolates based on lectin binding of cell extracts in an agglutination assay. J. Clin. Microbiol., 37 (6): 1994-1998.

6. Kuipers, E.J.; Sipponen, P. (2006). Helicobacter pylori eradication for the prevention of gastric cancer. Helicobacter., 11 (Suppl. 1): 52-57.

7. Lueth, M.; Sturegård, E.; Sjunnesson, H.; Wadström, T.; Schumacher, U. (2005). Lectin histochemistry of the gastric mucosa in normal and Helicobacter pylori infected guinea-pigs. J. Mol. Histol., 36 (12): $51-58$.

8. Melo-Junior, M.R.; Telles, A.M.S.; Albuquerque, F.E.B.; Pontes-Filho, N.T.; Carvalho, L.B.J.; Beltrão, E.I.C. (2004). Altered lectin-binding sites in normal colon and ulcerative colitis. J. Bras. Patol. Med. Lab., 40 (2): 123-125.

9. Moran, A.P.; Sturegård, E.; Sjunnesson, H.; Wadström, T.; Hynes, S.O. (2000). The relationship between O-chain expression and colonisation ability of Helicobacter pylori in a mouse model. FEMS Immunol. Med. Microbiol., 29: 263-270.

10. Ogata, M.; Araki, K.; Ogata, T. (1998). An electron microscopic study of Helicobacter pylori in the surface mucous gel layer. Histol. Histopathol., 13 (2): 347-358.

11. Özer, E.; Sarioglu, S.; Güre, A. (2000). Effects of prenatal ethanol exposure on neuronal migration, neurogenesis and brain myelinization in the mice brain. Clin. Neuropathol, 19 (1): 21-5.

12. Rameshkumar, K.; Cooper, R.; Jalihal, A.; Nirmala, V. (1994). Peanut agglutinin binding by gastric mucosal epithelial cells in Helicobacter pylori associated gastritis. Indian. J. Med. Res., 100: 26-30.

13. Sharon, N.; Ofek, I. (2000). Safe as mother's milk: Carbohydrates as future anti-adhesion drugs for bacterial diseases. Glycoconj. J., 17 (7-9): 659-664

14. Starzyñska, T.; Malfertheiner, P. (2006). Helicobacter and digestive malignancies. Helicobacter., 11 (Suppl. 1): 32-35.

15. Take, S.; Mizuno, M.; Ishiki, M.; Nagahara, Y.; Yoshida, T.; Yokota, K.; Oguma, K.; Okada, H.; Shiratori, Y. (2005). The effect of eradicating Helicobacter pylori on the development of gastric cancer in patients with peptic ulcer disease. Am. J. Gastroenterol., 100 (5): 1037-1042. 